\title{
Is the institutionalization of urban movements inevitable? A comparison of the opportunities for sustained squatting in New York City and Amsterdam*
}

Fourth

Preprint. Published in International Journal of Urban and Regional Research, 2003, Vol. 27, nr. 1, March, 133-157

\author{
Hans Pruijt \\ Erasmus Universiteit Rotterdam \\ PO Box 1738 \\ 3000 DR Rotterdam \\ The Netherlands \\ pruijt@fsw.eur.nl
}

\section{Introduction}

A housing shortage, combined with abundant empty property is just the basic condition for squatting ${ }^{1}$. Like any social movement, squatting takes place within an opportunity structure which determines if and how it can be developed and how effective it can be. In this paper, I seek to contribute to our understanding of the opportunity structure for squatting by means of a comparison between Amsterdam and New York. Clearly differing in terms of urban regime, both cities suffered housing shortages while many buildings were vacant. In Amsterdam, there has been extensive squatting; in New York, squatting has been markedly less, but still sufficient to allow some inferences about the opportunity structure for squatting.

Studying the opportunity structure for squatting is relevant because, despite having been prematurely considered passé (Van Noort, 1988, Mamadouh, 1992: 152), squat-

${ }^{*}$ I would like to thank all who supported this research by sharing information and viewpoints. I am also grateful to the participants in Session 3 of the ISA RC \#21 conference "Social Inequality, Redistributive Justice and the City", Amsterdam, June 15-17, 2001, and to Monique Hooghuis, Dick Houtman, Coos Huijsman, Paul Jansen, Matthew Lee, Cees de Leeuw, Chris Pickvance, Rolando Politi, Ines Pruijt, Michael Shenker, Inge Strubbe and two anonymous referees for their helpful comments on earlier versions. The usual disclaimer applies.

${ }^{1}$ Squatting is living in - or using otherwise - a dwelling without the consent of the owner. Squatters take buildings with the intention of relatively ( $>1$ year) long-term use. Unless specifically indicated, this paper is about squatters who repair defects in their buildings.

Dutch squatters started to use the term "krakers" to designate people who aim at turning their squats into long-term homes. In Berlin, the term "instandbesetzen", a conflation of "instandsetzen" (i.e. renovating) and besetzen (i.e. occupying) was invented. In the US, the term "homesteading" in contemporary usage means taking over an abandoned building and turning it into a home. Generally, this refers to property made available by the (local) state for this purpose. Sometimes US squatters use the term homesteaders as well.

One find uses of the term "squatting" in which its meaning is stretched. Newspaper reports sometimes use the term for people who just use buildings as crash places and who do not try to fix them. In the Netherlands it is sometimes used for people who inhabit an apartment with the consent of its owner but against the municipal low income housing allocation rules (Priemus, 1983). In the UK, people who rent short-life property have been called "licensed squatters" (Platt, 1980). The occurrence of squatting does not imply that there is a squatters' movement. Examples of squatting without a squatters' movement are: isolated self-help squatting, squatting by a relief organization for homeless people (a US example is Homes Not Jails (Corr, 1999)), squatting employed as a tactic by a neighborhood organization, for instance to obtain space for cultural activities, or squatting empty properties as part of a fight to prevent construction of infrastructure, e.g. roads. 
ting is still ongoing (Kallenberg, 2001: 92; Duivenvoorden, 2000). The squatting waves of the 1970s and 1980s were not the first: shortly after WW II, there was widespread organized squatting in the UK (Friend, 1980; Johnstone, 2000) and in France (Duriez and Chauvière, 1992). Nor may the most recent squatting waves be the last. Corr (1999: 185-188) predicted a rise in housing direct action in rich Northern nations and in formerly communist countries, because of the dwindling supply of affordable housing and increased inequality, plus decreased opportunities for raising the standard of living through the labor movement.

The aim of the paper is to use the New York-Amsterdam comparison to explore whether the opportunities for effective organized squatting depend on the urban regime, and specifically on whether it relies on market forces, or on state intervention and redistribution. I consider organized squatting to be most effective when for all types of empty building in the city (such as tenements awaiting demolition and eventual replacement by low-income housing, luxury housing kept off the market for speculation, disused office space, empty warehouses and factories) viable models for squatting have been developed and spread (so that all empty buildings in the city become squatted.) By "viable model" I mean a sustainable way to repair, heat and maintain buildings, and deal with owners, authorities and the community. Effective squatting also entails contributing to the push for a lively, low-income people-friendly city.

First I will review the relevant studies and theories. The key issue here is whether squatting leads to integration, repression, or some combination of the two. Two forms of integration are distinguished: institutionalization and cooptation. I shall argue that a market oriented urban regime is conducive to cooptation. I will then introduce the cases of the two cities and justify their choice, before presenting the comparison itself. I will start comparing processes of integration in the two cities. Although the literature tends to focus on integration, the protection of private property and the technical condition of buildings are also issues where the urban regime affects the opportunities for squatting. I therefore compare the cities on these points as well. I then consider a possible side effect of squatting that is especially salient in the context of a marketoriented urban regime: might squatting be self-defeating because it unleashes market forces that result in gentrification? I conclude the comparison by focusing on the one sphere in which a market-oriented regime seems to offer more opportunities for squatting: low-income housing rehabilitation.

\section{The integration of squatting, urban regime and the privatization of poverty}

Both repression and integration characterize the relations between the state and radical urban movements (Castells, 1977: 208-209). The squatting experience seems to conform to this pattern. Repression is evident in the actions of legislators who try to close any legal loopholes that facilitate squatting (Watkinson, 1980; Schuckink Kool, 2001: 23-25). Despite this, neither in the UK nor the Netherlands were the legal measures introduced to completely stamp out squatting. And in Germany, where squatting is illegal, squatters were not prosecuted to the full extent of the law (Artkämper, 1995).

The integration of squatting can take two different forms: institutionalization and cooptation.

\section{Institutionalization}

Institutionalization means that a movement is channeled into a stable pattern based on formalized rules and laws. Expected behavior becomes clearly defined; sanctions are 
in place. The institutionalization of a movement means that it loses its identity (Castells, 1983: 328). Institutionalization also implies a changed movement action repertoire: conventional methods take the place of disruption (Kriesi, et al., 1995).

The institutionalization of squatters is most evident when it takes the form of legalization. For example, in London, some 5000 squatters in Greater London Council property received an "amnesty", which entitled most of them to re-housing, prior to a crackdown (Platt, 1980: 89). As Platt (1985: 333) notes, in the UK, organized squatting declined more as a result of concessions than because of repression. In Berlin, between 1981 and 1984 local authorities eliminated squatting through a combination of repression and legalization (Mayer, 1993: 158-159).

The literature offers a wide range of possible reasons why authorities in different countries might favor legalization over repression.

Squatting has always enjoyed a level of legitimacy. Public support for squatting was unstable (Anderiesen, 1981: 86), but many saw at least some of the squatters as reasonable, rational, constructive people who focused on meeting housing needs or protested against housing shortages, vacancies or speculation (Priemus, 1983).

Media coverage of squatting campaigns has often been hostile, leading to a backlash in the form of a moral panic (Tromp, 1981; Platt, 1980: 59-63; Amann, 1985). Nevertheless, positive media coverage, e.g. (Hollister, 1972: 48-49; Bailey, 1973; Borgos, 1984: 18) is also widespread. Respected public figures have come out in support of squatters, for example by protesting against proposed anti-squatter legislation in the UK and the Netherlands or, in Berlin, by actually staying in squats that were threatened with eviction (Mulhak, 1983).

Legalization may be a matter of authorities rationally calculating that pure repression is too expensive. According to Platt (1980: 89-90), the legalization of 5000 squatters in London in 1977 came about because evicting them would have been impossible.

Squatters themselves are drawn towards legalization because squatting is not only a political activity but an economic activity as well. This distinction was made by Cherki (1973) in his analysis of squatting in France. He showed that there was a divergence between squatters' political aspirations (changing the course of urban restructuring to reflect the interests of the working population) and economic demands (suitable rehousing of displaced tenants). The squatting campaign in Paris was organized by politically motivated activists who opened up houses for people in distress. It proved to be possible for the two groups to work together, but the housing needs of the distressed precluded the pursuit of political goals (Anon, 1972). Bailey (1973) convincingly conveys that activists, who have taken poor families under their wings, have little other option but to accept solutions that entail security.

We should not underestimate the role of repression as a force that pushes squatters towards institutionalization. Negotiations may at least delay eviction or even lead to legalization; involvement in neighborhood politics and planning allows squatters to find allies and show themselves as constructive citizens, which has a moderating effect on repression; proposed anti-squatter legislation drives squatters to establish channels for lobbying.

Some authors suggest that organized squatting is not as radical as it may seem. Cant (1979) came to this conclusion, because in the UK, squatting in private sector dwellings tended to remain at an unorganized level, while squatting in the public sector became well organized. And Lowe (1986: 138) stated: "the issue of private property 'rights' was transformed into a generalized critique of the public sector" (for its inefficiency which revealed itself in the form of vacant buildings). 
The dominant view of urban movements is that they have a life cycle, in the final phase of which institutionalization takes place. Castells (1983: 328) for example, concluded that the institutionalization of urban movements with its attendant identity loss is inevitable. And research into protest waves showed that institutionalization (a shift in the action repertoire from disruption to convention) tends to appear near the end; in protest wave theory, institutionalization is a phase between protest and reform (Kriesi et al., 1995).

Some authors, however, have maintained that institutionalization does not have to be associated with a movement's decline. A movement may only be partly integrated, while a radical wing continues to produce disruption. The integrated moderates can then reap the concessions made in response to the disruption wrought by the radicals. Also there may be opportunities for movements to remain entirely within oppositional civil society (Dryzek, 1996). And when movements leave disruptive tactics and turn to a more institutionalized repertoire of action, this may enable them to attract more supporters (Tarrow, 1994: 114). Tarrow (1994) also argues that contemporary social movements tend to be flexible, i.e. their repertoires span disruptive and institutionalized actions. To summarize: it is possible to distinguish a terminal and a flexible type of institutionalization.

Terminal institutionalization implies that, in the repertoire of action, convention replaces disruption; in flexible institutionalization, conventional tactics complement disruptive ones.

\section{Cooptation}

The second integrative mechanism is cooptation, which in my view means that the coopting organization embraces certain ideas from the movement, while redefining problems in such a way that solving them does not threaten its own stability. The coopting organization shapes a framework in which it gives co-opted activists a role. ${ }^{2}$

Authors differ as to whether co-optation is just a manipulative device for bolstering legitimacy of authority (in other words, a "sell-out" of those co-opted) or whether it involves new constraints on the co-opting organization. Selznick (1949) allowed for both possibilities, depending on whether those being co-opted represented a real power centre or not. On the other hand, Piven and Cloward's (1977) main conclusion after studying several movements was that when movements achieve results, this is because of institutional disruption. In this view, cooptation would be a pure loss for the movement. Corr (1999: 136-139), however, pointed out that all squatters must sooner or later be prepared to negotiate with the state and be co-opted, because this is the only way to consolidate what they have achieved. The position taken in this paper is that the costs and benefits of cooptation need to be analyzed on a case-to-case basis.

A salient example of cooptation can be found in the history of squatting in the UK. There, some squatters' organizations were transformed into management offices that rented out short-life public sector accommodation. This was called "licensed squatting" (Bailey, 1973). The deals with local authorities, that made this possible, required squatters' organizations to give up organizing squatting. Lowe (1986: 148) called licensing "a classic example of the cooptation of a critical social movement." He also

${ }^{2}$ This is based on Selznick's (1949: 13) definition of cooptation as "the process of absorbing new elements into the leadership or policy-determining structure of an organization as a means of averting threats to its stability or existence" while taking into account the observation by Warren, Rose and Bergunder (1974: 56) that cooptation involves changing the definition of problems in such as way, that their solutions are compatible with the stability or existence of the co-opting organization. 
noted that licensing caused division of the squatters' movement into a licensed and an unlicensed wing, and gave councils leverage for repressing the unlicensed part.

Functionalist reasoning may provide some explanation for the cooptation of squatters. Some authors suggest useful functions that, in the eyes of state officials, squatters' movements might fulfill. Squatting is a way of providing last-resort housing solutions. There have been instances in which social workers and also the police approached squatting organizers in order to find homes for difficult cases (Bailey, 1973; Platt, 1980: 48). In the Netherlands, subsidized youth support organizations did a lot to get squatting started. Self-help is also a cheap solution, which may appeal to authorities interested in cutting housing costs (Platt, 1980: 90). Draaisma and Hoogstraten (1983: 410-411) noted that labor movement and left-wing parties criticized squatters for creating substandard housing, thereby causing a risk of "self-amputation" of the welfare state. Finally, squatters' movements create breeding places where artists can work; innovation in informal spaces contributes to the vitality of the city (Breek and de Graad 2001).

Piven and Cloward (1977: 33-34) suggested that the effect of cooptation on a movement is pervasive, not only because leaders are attracted by the new opportunities and followers are conciliated, discouraged, and remaining radicals repressed: cooptation also removes opportunities for radical (re-)mobilization because it allows the state to show itself as a responsive problem solver. Moreover, concessions given to the movement antagonize parts of the population.

\section{Urban regime and cooptation}

If the general trend is predominantly one of repression and integration of squatting, does it make any difference if the urban regime is strongly market-oriented or not? An answer to this question is provided by post-Fordism theory. The logic suggested by this theory is as follows. As the cost of the welfare state tends to grow, this prompts cuts in government spending or attempts to keep costs under control. Furthermore, bureaucratic state-provided solutions, especially those involving redistribution of wealth, are criticized as inefficient, and as counterproductive because they do not stimulate initiative. Finally, the ethos of competition becomes stronger. Despite this, the state continues to pursue alleviation of poverty as one of its objectives, and as a result is faced with conflicting demands.

Under these conditions, a logical step for policy makers is to encourage and support self-help initiatives. This has been called the "privatization of poverty" (Von Hassell, 1996: 175). Increasingly, profit oriented parties and non-profits become involved in the provision of social services such as low-income housing; existing neighborhood groups can be co-opted to function as plugs for holes left by the retreating state. In the US, neighborhood groups stepped into the new management roles, because they found it increasingly difficult to mobilize tenants. Organizing rent strikes, for example, was no longer effective since it would only stimulate landlords to abandon their buildings. More and more, neighborhood groups became financially dependent on the state which subjected the groups to bureaucratic demands. This caused them to concentrate on managing rather than on taking action and organizing the neighborhood. Technical assistants were hired to mediate between neighborhood groups and the state. Also, neighborhood groups became involved in multimillion-dollar renovation and construction projects. Some would win contracts for providing social services. Finally 
several of these neighborhood groups came into conflict with tenants (Castells, 1983: 64; Katz and Mayer, 1985). ${ }^{3}$

Thus, following the post-Fordist logic, we would expect that in an urban regime that relies less on redistribution and intervention and more on market forces, state officials will feel a greater need to co-opt urban movement groups. Under these conditions activists should expect some influence in return for being co-opted, since their interest is related to a "state imperative" (Dryzek, 1996: 479): the state still has a responsibility for the living conditions of citizens, while officials have their hands tied because the emphasis in politics is on letting the market do its work and on promoting competitiveness.

With this 'functionalization' of community groups for state policy, a new field of action opens up. As Mayer (1998: 69) writes "the opening-up of the urban governmental system has included many of these groups, as it became the strategy of many municipalities to employ former social movement organizations in the development and implementation of (alternative) social and cultural services, of housing provision, and local economic development." Post-Fordist theory not only predicts stronger pull factors towards cooptation under a market-oriented regime, but also predicts greater push factors in the form of repression. This is because cities engage in competition for attracting visitors and business. In this competition having a clean, safe, respectable image is important.

To summarize our theoretical argument: the literature points to three different ways in which integration can complement repression:

- Flexible institutionalization, which entails opportunities for effective squatting.

- Terminal institutionalization, which is associated with the end of the movement.

- Cooptation, when oppositional groups are transformed into service providers. In this scenario, squatting itself is abortive, but it may be a launch pad for third sector activities in cooperation with the state. This scenario is more likely under a market oriented urban regime.

\section{The cases of Amsterdam and New York City}

Our decision to choose New York and Amsterdam was to compare two cities that both had the obvious preconditions for large-scale organized squatting: a housing shortage and an abundance of vacant buildings, but which differed greatly in term of the urban regime. ${ }^{4}$ Their similar housing situation can be seen from the following. In

3 Schwartz (1986) describes the transformation of radical New York tenant organizations into voluntary social service providers that were "effective at helping individuals in distress but without the power to stir collective action for basic social change".

${ }^{4}$ This paper is based on research undertaken in New York City and in Amsterdam.

In 1983, I tried to establish whether there were any squatters on the Lower East Side of Manhattan by contacting neighborhood organizations and organizing the screening of the film "You can't live in a tank" about squatting in Amsterdam, followed by a discussion. The screening was advertised on posters that were put up around the neighborhood.

Between 1995 and 1999 New York squatters published various documents on the World Wide Web. They allowed the construction of an outline of the history of squatting the Lower East Side, and pointed to possible contacts. In 2000 I interviewed seven activists, participated in a demonstration and a strategy meeting concerning community gardens. I studied all news articles (278) on squatting in New York City that could be retrieved from the Lexis-Nexis database as well as background documents on housing policy in New York that were available online. Through newsgroups I located a Dutch squatter who had started a squat in the Lower East Side with whom I had a long interview. In 2001 I interviewed four more activists in New York. I also had 
1983 thousands of New Yorkers, who were unable to find affordable housing, lived in the streets. An example of what the New York housing market had to offer: a two room apartment in a run down building on the Lower East Side could be rented for $\$ 800$ a month. At the same time, entire buildings stood empty. Amsterdam also suffered a severe housing shortage. Although few people were out on the streets in this city of 700,0000, in the early 1980 s some 50,000 citizens were on the municipal waiting list for low-income housing.

The two cities represent different types of urban regimes due to their placement within different types of national welfare state regime. Esping-Andersen (1990: 26-27) characterized the US as having a "liberal welfare state regime", which entails that the state "encourages the market", "minimizes de-commodification effects" and "effectively constrains the realm of social rights". The Dutch welfare regime has traits of the "social democratic" type, which means that the state promotes an "equality of the highest standards, not an equality of minimal needs". Fainstein (2000: 106) notes that in Amsterdam, the state continues to use physical planning and social welfare expenditures to maintain equality, while New York City "has virtually abandoned planning except for specific projects and has dramatically cut back on social spending".

The intensity of squatting differed greatly between the two cities,. According to a 1981 study (Van der Raad, 1981) Amsterdam housed around 9,000 squatters. At least temporally, squatting made a dent in the city's housing problem. The squatters' movement built an infrastructure with advisory services for aspiring squatters in several neighborhoods, telephone trees, media, bars and restaurants, theaters and concert halls, workshops, a medical service and a bureau that investigated real estate speculators. In New York, while there was some squatting in the early 1970s, organized squatting disappeared until around 1983 a squatters' movement developed on Manhattan's Lower East Side. But, compared to Amsterdam, it remained small: at its peak, 500 squatters lived in 20 buildings.

\section{The Integration of Squatting in Amsterdam}

The pattern observed by comparing squatting in Amsterdam and New York almost conforms to the pattern described above in the section on integration, urban regime and the privatization of poverty.

The Municipality of Amsterdam bought two hundred of the buildings that were occupied by squatters (Duivenvoorden, 2000: 323), thereby legalizing them. Officials turned most of these buildings over to established housing associations, which concluded lease contracts with individual squatters (Draaisma and Hoogstraten, 1983). Soja (2000: 124) labels this policy as "slightly repressive tolerance".

conversations at relevant organizations: UHAB (Urban Homesteading Assistance Board, ACORN (Association of Community Organizations for Reform Now) and Community Board \#3. I studied Community Board \#3's archive regarding a cross subsidy plan that involved various squatted buildings. Two long-time activists whom I had not interviewed, one from the Lower East Side and one from the South Bronx, wrote comments on the first draft of my research report. Iterative e-mail contact with them led to further clarification.

In Amsterdam, research mainly took place from 1980-1984 in the shape of interviews and examination of archives (Pruijt, 1984; Pruijt, 1985; Huijsman, Pruijt and Strubbe; 1998). After 1984 I kept collecting documentation. Important sources of information were the main squatters' periodical (Kraakkrant, 1976-1981) and its successors (Laatste Waarschuwing 1981, Bluf! 1981-1988, NN 1988-1995, Ravage 1996-2002). In contrast to New York, an extensive descriptive literature about the Amsterdam squatters' movement exists (see references). Therefore, no further collection of primary data on squatting in Amsterdam was necessary. 
Legalization involved many squatters in construction planning and in negotiations with municipal officials. Outside the context of legalization, there were also many contacts between squatters and state officials. The municipality offered to make repairs to some of the squats that were slated for eventual demolition, to help keep the buildings habitable in the meantime. Subsidized neighborhood centers, along with Church groups, represented squatters' views. In many neighborhoods, for instance the east docklands, squatters took part in city planning. In many conflicts, politicians mediated.

However, contrary to what the urban movement literature - and much of the general social movement literature - tends to suggest, there was no loss of identity in terms of willingness to cause disruption. Squatters continued to defend buildings which the municipality was unable or unwilling to buy and legalize. In 2000 for example, squatters mobilized to defend squatted warehouses, which involved raising bridges; and riots developed, for example at the coronation of Queen Beatrix in 1980. Squatters also played a major role in urban protests, for example against the construction of the new town hall or the against the city's campaign to attract the Olympic Games. Seen from the level of the movement as a whole, this shows that institutionalization did not entail constraints on the repertoire of action; disruptive and conventional tactics existed side-by-side. Squatting in Amsterdam continued to be effective. There is no indication that, between 1978 and 2000, squatters missed opportunities for squatting.

Nor was institutionalization in Amsterdam an end of life cycle phenomenon. The heyday of legalization was in the early 1980s. Two decades later, squatting was still going on. One observer, Van Noort (1988: 180) suggested that concessions even contributed to the radicalization of the movement.

The Amsterdam squatters' movement shows that flexible institutionalization of an urban movement is possible.

Contrary to the predictions of post-Fordist theory the evidence of cooptation (conversion of oppositional groups into social service providers) in Amsterdam is extremely limited. Squatters' groups were not transformed into organizations employed as providers of state-neglected services. In Amsterdam, third sector organizations were especially important in the provision of social housing. These organizations did not however originate in urban movements.

\section{Integration of Squatting in New York}

In contrast to Amsterdam, and in line with the urban movement literature and postFordist theory, squatting in New York tended to be a transient phenomenon disappearing in the wake of cooptation of housing movement groups. New York City saw a squatting wave ${ }^{5}$ in 1970 (Brotherton, 1978), but this wave quickly died out. An electronic search in the abstracts of the New York Times showed that 13 articles on squatting actions appeared in 1970, three articles in 1971 and in 1972 and then nothing until 1980.

Squatting in New York clearly met with repression. A few examples: in 1970, squatting-related arrests reported by the New York Times totaled 56; in 1981, the city evicted tenants who had taken over their buildings (Katz and Mayer, 1985: 24).

\footnotetext{
${ }^{5}$ One the campaigns was known as "Operation Move-in". One of the organizations involved was "Neighborhood Save Our Homes".
} 
However, the shift in the housing movement away from confrontation and toward cooperation with the city can also be linked to the decline of squatting.

\section{Organizers and supporting organizations leave the squatting scene}

Organizers left the squatting scene (Brotherton, 1978: 169-170) and housing movement organizations that had supported squatting, such as UHAB (Urban Homesteading Assistance Board) turned to working with the local government. A key challenge that urban movement groups responded to was helping thousands of low-income tenants in buildings that were at risk of becoming inhabitable save their homes. These buildings had become city property because of tax arrears. The city sought to place these buildings with private companies, but acting on prompts from the urban movement scene it also instituted "alternative management programs". Two of these programs involved the use of community groups and tenants as managers. ${ }^{6}$ The experience gained with the Tenant Interim Lease (TIL) program showed the ambiguities of the privatization of poverty. The TIL program gave tenants the opportunity to manage their buildings by themselves, with the possibility of eventually obtaining ownership as a cooperative. This seems to illustrate that self-help may serve as an excuse for allocating less money as compared to normal social service provision. Katz and Mayer (1985: 21-22) stated that the alternative management projects received less than half of normal housing subsidies, while the median income of occupants of the taxforeclosed properties was only $60 \%$ of that of all New York renters. Moreover, the TIL program also seems to illustrate how self-help forces potential activists to concentrate on survival rather than on mobilization and political influence. Katz and Mayer (1985: 21-22) indicated that the effect of the Tenant Interim Lease program on the neighborhood movement was, that the difficult struggle to keep their buildings afloat absorbed active tenants' energies. However, the program and the investment in it by tenants and activists served a sizeable need. After its start in 1976, TIL continued throughout the remainder of the 20th century. Between 1976 and 1996, nearly 1000 buildings had entered the program of which twelve per cent had dropped out. (Note that quantitatively, this program is an order of magnitude larger than all squatting in New York combined.) The role of UHAB in the TIL program was providing training and support for self-managing tenants).

\section{Official homesteading}

Not only did organizers and supporting organizations leave the squatting scene, but there were also initiatives to "tame" squatting by setting up official "homesteading" programs (Borgos, 1986: 432). Homesteading programs offered citizens, organized in groups, the opportunity to fix up abandoned, city owned buildings, with the promise of eventually obtaining ownership of their apartments (without the right to sell these at a profit). Church-related social reform organizations had initiated the programs and also offered organizational support. Participants put in work ("sweat equity"), while contractors performed the required skilled construction tasks. Subsidies and loans provided the funding; the programs enjoyed mainstream political and media support. ${ }^{7}$

${ }^{6}$ Katz and Mayer (1985: 28-33) described how the New York neighborhood movement was restructured from a "self-help" housing struggle into state-controlled programs. They concluded that: "in this process, self-help was transformed from an oppositional practice into a state-organized norm of organization and control" (Katz and Mayer, 1985: 33).

${ }^{7}$ Some examples of a transition from squatting to official homesteading: In New York, some of the squatters were offered an abandoned building to start a homesteading project (Lawson 1986, section "Watershed for the Tenant Movement, 1970 - 1975"). Von Hassel (1996: 24) mentions an early project in 1967 that was "not cleared with the city" (i.e. squatted) as a predecessor of official homesteading. And some of the buildings 
Reflecting on the findings obtained in her ethnographic study of homesteading on the Lower East Side, Von Hassel (1996: 35) asked "are the concepts of empowerment and self-help nothing but ideological traps to distract and occupy the restless poor?" Homesteading turned out to be a tortuous process. It took between six and ten years to complete a building and in some cases even thirteen years. Financial worries plagued the renovation projects, even causing some people to give up after three or five years of work. Bureaucracy was a source of stress, and participants became hostile towards the supporting organizations. These, in turn, gave up their interest in homesteading. After completion, the buildings remained financially insecure. Gradually, the political attitude of the participants underwent transformation. In the beginning, they identified with squatters. Some homesteaders had started work on their buildings before they were accepted into one of the programs. An important difference between homesteading and squatting is, however, that homesteaders do not live in their building until renovation is completed up to building code. Over time, homesteaders began to see themselves as homeowners, and on this basis became opposed to squatters. This meant a split in the movement against displacement (Von Hassel, 1996). In some cases, homesteading involved a chain of cooptation. The city made use of activists (in the church organizations) to get buildings renovated. In turn, the activists of one of these organizations, LESAC (Lower East Side Catholic Area Conference), pressed the homesteaders (who were poor and overburdened themselves) into providing housing to homeless people sent by another church-related organization (Nazareth Home). (Von Hassell, 1996: 99-101). These homeless people themselves did not have to participate in the sweat equity work.

\section{Transformation of organizations that had been involved in squatting}

A final effect of cooptation on squatting in New York is the transformation of the organizations involved in squatting. Some of the community organizations that figure prominently in the urban studies literature, such as Banana Kelly and ACORN, employed squatting as a tactic when they were starting out. When these organizations transformed they left squatting behind.

Acorn (Association of Community Organizations for Reform Now), with 75000 members and branches in 27 states, for instance, in 1985, organized the squatting of 25 buildings in Brooklyn. The city had originally planned to auction these buildings off. After the squatting action, the city changed its policy and turned 58 buildings over to ACORN/Mutual Housing Association of New York, which incorporated the squatters. The city provided funds for rehabilitation. However, the city was willing to do so only after Acorn had promised to abandon squatting (Erlanger, 1987).

In the South Bronx, Banana Kelly started with squatting on Kelly Street. Then it switched to renovation work, later to move to promoting local economic development.

Banana Kelly became known as the star model of using the opportunities offered by the tendency for municipalities to employ former movement groups. It rehabbed and managed low-income houses. It became involved in education and training, economic development and job creation. One of the most notable projects was the planning of a paper-recycling mill. Banana Kelly received a Best Practice Award at the Habitat Conference in the summer of 1996. It was featured in the program of Expo 2000 in Hannover; information about Banana Kelly was disseminated as a best practice case to German schoolchildren. 
However, from 1991, while Banana Kelly was on its way to international fame, it found itself running into problems. Under the leadership of a new chairwoman, a financial scandal developed. Meanwhile, its tenants complained about rats, bad maintenance and lack of heat. In 2001, its last buildings were taken over by another nonprofit organization (cf. Waldman, 2001).

The conclusion so far is that in New York, the pattern is that squatting tended to be marginalized as organizers and supporters turned to working with the city, initiatives appeared to transform squatting into regulated self-help renovation, and organizations that started squatting were transmogrified into service providers. This pattern is consistent with post-Fordist theory. This, however, does not imply that, under a market oriented urban regime, the marginalization of squatting as a result of cooptation is inevitable.

\section{The anomalous emergence of a squatters' movement in New York}

In New York City, after 1983, organized squatting re-emerged on the Lower East Side. The difference with the previous squatting wave was that now a real squatters' movement, i.e. a movement in which squatting and the defense of squats were central, developed. There were no signs that this squatter movement was co-opted by the state, nor repressed out of existence. And it took two decades for the first sign of institutionalization to appear: only as late as 2002 were eleven squatted buildings on the Lower East Side legalized. This legalization only took place at the time when there were no squattable buildings on the Lower East Side left, which means that it can be classified as terminal institutionalization. There was little space for flexible institutionalization. Despite systematic probing, I could find few indications of talks between on the one hand, New York squatters, and on the other hand, officials and politicians. There were only two exceptions: arts/community center ABC No Rio, after city officials had for nearly twenty years been trying to make it disappear - for example by cutting the water supply, was finally bought by its users for $\$ 1$. Conditions were that users had to raise $\$ 200,000$ in renovation capital, and that the squatters who also lived in the building had to go. The second exception was that one judge (Judge Wilk) showed that he was receptive to squatters' arguments during an eviction procedure, by granting a "stay". However, another judge quickly overturned this ruling. Over the years, New York's municipal officials maintained a consistent line of not negotiating with squatters. (The case of ABC No Rio fits into this picture, since officials eventually were willing to talk to users of the center, as opposed to the squatters who were living on the upper floors.) The legalization of eleven squats on the Lower East Side in 2002 required no contact between squatters and city officials; it became possible through the mediation of UHAB. ${ }^{8}$

Why was this movement not co-opted? One possibility that needs to be considered is that after 1983, the window of opportunity for cooptation closed, i.e. city officials were no longer interested in co-opting movement groups. This possibility can be dismissed however, because in 1992 the city tried to co-opt a squatting group in the

\footnotetext{
${ }^{8}$ The difference between the two cities in terms of access to the political system fits in with Tarrow's (1994: 90) assessment: "the American state, though weak in relation to business, is quite strong when it comes to labor and national security. As a result of this difference, it presents an open door to groups which advance modest goals (..) but sets up a barricade against those who challenge property or security." Within New York, the defenders of community gardens found a level of access to the political systems that squatters did not enjoy. The State of New York, for example, initiated a lawsuit against the City of New York to prevent the city from selling off community gardens to developers. City and Federal officials offered support to community gardeners. This also supports the thesis that the US political system is highly selective in terms of granting access.
} 
Bronx, ICP/Community on the Move. The offer was to legalize three buildings, on the condition that all other squatters would leave their buildings, and to turn ICP into a non-profit social service provider and to supply it with contracts.

The conclusion is, that the explanation for the immunity to cooptation of the Lower East Side squatters' movement is unlikely to be found in the context; we need to focus on the movement itself.

\section{Two types of squatting}

However, it seems not just a matter of strategic choice on the part of the squatters whether to go the cooptation route or not. The reason for taking this view is that there are many indications that we are dealing with two different kinds of squatting.

On the one hand, there is squatting that is undertaken as a tactic by the New York housing movement. This is the case with the New York squatting initiatives that terminated in the wake of cooptation. On the other hand, the post-1983 squatting on the Lower East Side had more in common with the Amsterdam squatters' movement than with the other squatting initiatives in New York. Both are examples of a squatters' movement proper, which means that squatting itself is means and primary goal at the same time.

In a squatters' movement, squatting itself is at the center. It is a community of squatters who co-operate when new buildings are squatted and in the defense against evictions. Organization is bottom-up and network structured. There is little formal organization; informal leadership exists however. Motives for participation vary. Some elements are: meeting personal housing needs, creating an alternative lifestyle and practicing a type of politics that yields tangible results. Not all participants need to live in squats themselves. There is a do-it-yourself ethic ${ }^{9}$ and an ideology of selfdetermination. Obviously, participants tend not to be wealthy, but some of them are rich in social and cultural capital, e.g. artists and students. For those who are not, squatting is difficult. Squatters on New York's Lower East Side hit this limit when they tried to engage the homeless that used to live in Tompkins Square Park.

Fun and partying are always important. There is a tendency to offer services to the larger community, in particular by providing cultural centers or performance spaces. Squatters' movements are part of a "left-libertarian social movement family" (della Porta and Rucht, 1995), including for example the ecology movement and the new peace movement. The movements within this family have organizational overlaps. In one of the few published papers on squatting in New York City, Van Kleunen (1994) writes that from 1985, newly created squats were more political, and that cooperation between squats developed. This observation supports the interpretation that around that time, a squatters' movement had been built.

\section{What makes a squatters' movement resistant to cooptation?}

One possibility to consider is that the participants in a squatters' movement care more about autonomy than the participants in a housing movement do. Katz and Mayer (1985) thought along these lines when they compared "self-help housing struggles" in New York City (prior to 1983) and West Berlin. In West Berlin, cooptation of the squatters' movement did not come about. Mayer and Katz locate the determinant for

${ }^{9}$ An example: in Amsterdam there were neighborhood based squatter advisory desks. Their policy was to restrict themselves to supporting people who were interested in squatting, supply them with information, and perhaps link them up with experienced squatters who might provide physical assistance. 
incorporation in the goals of the activists. They indicate that the squatters in West Berlin were not incorporated because their struggle went beyond housing, involving "power and control of space, and the capacity to define alternative visions of life and the future" (Katz and Mayer, 1985: 41). This antagonized the politicians in power who, in turn, closed the door to incorporation of the squatters as a state-recognized self-help organization. However, as Mayer and Katz (1985: 16) themselves state, the New York housing movement embodied a need for autonomy and self-management as well. This is not far removed from the motives that they ascribe to the squatters in Berlin. It would be premature to state that a desire for autonomy plays no role at all, but it seems necessary to look for clearer differences between the two types.

Closely related to the preceding point, many authors have tended to see squatting - or at least the actions of certain squatter groups - as a way of satisfying a need for counter cultural political expression (Van der Loo, Snel et al., 1984). If the essence is counterculture, there would be some logic in seeing this as a source of resistance to cooptation. However, researchers who have tried to establish why people were squatting found that counter-cultural motives were at most secondary to meeting housing needs (Kinghan, 1977; Van der Pennen, Bertram et al., 1983). Kinghan (1977: 80) suggested that the experience of squatting itself can lead to political radicalization. ${ }^{10}$

Besides a possible varying emphasis on autonomy and counter-cultural expression, there is more difference between a housing movement and a squatters' movement in terms of goals. In the first type, the goal is to house poor people, or for poor people to obtain decent accommodation, and squatting is a means towards that goal. We are not dealing with a squatters' movement, but with a housing movement, for which squatting is one of the possible means that can be employed. In the second type, the act of squatting itself is, in the broad sense of the term that Berger and Luckmann (1967: 70$85)$ give it, institutionalized. The squatters' movement has an identity of its own.

In explaining susceptibility to cooptation, this distinction between a housing movement (for which squatting is one of the possible means that can be employed) and a squatters' movement is crucial. This is because cooptation implies that the state officials accept the ultimate goal of the movement (in this case providing homes for lowincome people). Then, the state officials can offer support to activists provided that the latter stop using oppositional means (squatting) and switch to state-approved means.

However, when squatting is not only a means but also a goal, it becomes difficult for state officials to claim that they share the same goals as the movement. This difference holds both for people who squat for themselves, and for organizers of squatting actions.

\section{Explaining the emergence of a squatters' movement in New York}

The emergence of a real squatters' movement in New York runs counter to what postFordist theory would lead us to expect. But it would be premature to call the adequacy of the theory into question, because the emergence of the squatters' movement on the Lower East Side was not entirely endogenous. The squatters' movement has, to some extent, globalized. Self-labeling of squatters involves the use of the international squatters' sign (a circle crossed by a lightning-shaped arrow). Europeans participated in the New York squatters' movement. An Italian artist who stayed in anarchist circles

\footnotetext{
${ }^{10}$ It seems reasonable to assume that organizational factors play a part too. A loose, informal type of organization may not be conducive to cooptation.
} 
in Berlin heard that there were hundreds of abandoned buildings on the Lower East Side. In 1981, he found a block of three buildings with only a sprinkle of "surviving" tenants. He organized squatting of the vacant apartments, and later went on to organize squatting of six more buildings. Arriving in the New York scene in 1985, a British woman introduced political ideas that were common in Europe. In 1988, a Dutch girl took the initiative to open up a large building in New York. She had previously squatted in the Netherlands and tried - with partial success - to introduce the cooperative features that were common in the Netherlands, such as a squatters' bar, regular consultation and mutual support between buildings, a tool exchange, facilities for artists and a theatre. In turn, American squatters made visits to European squatters' movements.

I am not claiming that external influence can make the local opportunity structure irrelevant. However, the role of external ties in the emergence of the Lower East Side squatters' movement shows that a pre-existing oppositional identity can to some extent override the opportunity structure. ${ }^{11}$

\section{The protection of property against squatters}

In New York, the emergence of a squatters' movement, as opposed to a housing movement, was anomalous but not impossible. But, once under way, the squatters' movements in the two cities faced different opportunity structures. An important difference is that in the US the protection of property against squatters is stricter and more straightforward than in the Netherlands. In the US, squatting is illegal, and squatters can be prosecuted for trespassing.

In the Netherlands, there is some legal protection for squatters. In 1971, the Dutch Supreme Court decided that the "house right", which protects homes from being entered against the will of the occupants, applies to squatters. From that moment, it became illegal for landlords to evict squatters and squatting was no longer considered to be illegal, provided that the building was neither in use nor being worked on. Often squatters would invite the police into a newly squatted building to allow them to see that the owner was not using it. This made it less likely that the owner would be successful when trying to press charges for trespassing. When eviction on the basis of trespassing was impossible, the only legal way for owners to evict squatters was to take them to court in a civil case. For years, squatters used to prevent this by keeping their family names secret until a change in law made it possible to sue anonymous occupants. In 1978, a proposed anti-squatting bill failed in parliament after lobbying by the Council of Churches. Instead, more than a decade later, legislation was passed that only protected those buildings that were registered in a special file for vacant buildings. At the same time, local governments obtained the right to claim registered buildings as housing for those in need. This legislation was not effective, and in 1994 a change in the law made it illegal to squat a building that had been standing empty for less than one year. Also in many cases squatters did not receive the protection they were entitled to; there have been illegal evictions. Although it has been eroded over time, some legal protection for squatters in the Netherlands squatters still exists. Zahn (1993: 393) writes that the Dutch have an exceptional tolerance for squatters. Nevertheless, in the Dutch legal system there is a tendency to outlaw squatting; the legal space for squatters that exists is the result of legal and political action by organizations that support squatting and of the slow speed of the legislative process.

\footnotetext{
${ }^{11}$ This case cannot be understood within a framework that treats movements entirely as the products of opportunity structures (see Goodwin and James, 1999).
} 
The history of squatting in the Netherlands (Duivenvoorden, 2000) clearly shows the effect of legal protection. The 1971 Supreme Court decision that gave squatters protection meant a turnaround. Prior to that point, the police had evicted squatters swiftly and it proved impossible to establish long-living squats. This changed completely. Squatters were now even able to re-squat and finally secure some buildings from which they previously had been evicted (Duivenvoorden, 2000: 69). The erosion of squatters' rights after 1986 also coincided with the decline of the movement (Duivenvoorden, 2000: 301).

In the US, there is no legal protection for squatters. There are lawyers who regard the eviction of people who fixed up an abandoned building as an injustice. In New York, two lawyers tried to help squatters obtain title to their squat on the basis of adverse possession. Adverse possession is the principle that when A uses a property owned by $\mathrm{B}$ for a number of years (in this case ten years), and, during all those years, B did not show the slightest interest in this property, the title goes to A. So far, there is no result.

To minimize the risk of being evicted as trespassers, New York squatters resort to two strategies. The first strategy is concealment from the authorities. Squatters introduce themselves to the neighbors and try to establish a good relationship with them, but are afraid that the police or housing authorities might find out about their existence. A New York squatter saw this as markedly different from Europe, "where squatters put out banners right away". In Amsterdam covert squatting has occurred as well, but in many cases squatters put out proud signs announcing that their building was no longer empty.

Covert squatting implies isolation: squatters or people interested in squatting cannot find each other. Back in 1983, I tried to find out whether there were any squatters on the Lower East Side by asking neighborhood and housing activists. No one new of any. Yet already since 1980, in Rivington Street, there existed the squat/art gallery/performance space/community center ABC No Rio. One of the squatters, whom I interviewed in 2000, found himself homeless in the early 1980s. He started living in an abandoned building and fixed it up. After 18 months he was discovered and given a prison sentence for breaking into the building. He was completely isolated from other squatters to the extent that he did not know that what he was doing was squatting. Nor did he find out about the existence of ABC No Rio. Thus the absence of rights gives rise to covert action which diminishes the likelihood of cooperation and selforganization.

The second strategy for avoiding being evicted as trespassers in New York is by restricting squatting to city-owned buildings. Compared to Amsterdam, this is an important difference. In Amsterdam, hundreds of privately owned buildings have been occupied by squatters, in addition to the massive squatting in city-owned property.

This goes a long way towards explaining why, while there is no legal protection for squatters in the US, squats in New York may last as long as squats in Amsterdam. ${ }^{12}$ Buildings vary in the risk of eviction when squatted. The risk is high when the building is privately owned for the purpose of making a profit. The risk is lower when the building is owned by the city, and when there are no concrete redevelopment plans. In New York, squatting is focused on this latter, low risk category. The New York squatters' manual also recommends choosing city-owned buildings because evicting squatters is easier for private owners.

\footnotetext{
${ }^{12}$ In 2002, some of the squats on the Lower East Side had existed for seventeen years. Such longevity can also be found in Amsterdam.
} 
The avoidance of privately owned buildings has a political effect, since it causes a squatters' movement to leave speculators in peace.

\section{Technical condition of buildings}

A further difference between New York and Amsterdam is that technical obstacles to squatting were more severe in New York. This can be seen by comparing squatters' manuals. The New York manual explains to would-be squatters how to assess whether a building is in danger of collapsing. It prepares them to deal with roofs with big holes in them, rotten timber and floors, missing water pipes, staircases with missing steps and the need to provide a front door and doorframe. As far as the manual goes, the squatters should not expect to be able to install flush toilets. Elsewhere in the New York squatting literature, we see a particular squat described as having flush toilets as a special feature. By contrast, the 1996/1997 edition of the Amsterdam squatting manual does not mention any construction-related hurdles. The earlier edition from the 1980s contains some construction advice, without suggesting that extensive damage was the most likely condition that squatters would encounter. A New York squatter wrote about Amsterdam: "Dutch squats had flush toilets, restaurants, radio stations but all this luxury just made squatters cynical" (Tobocman, 1999: 238).

The technical condition of abandoned buildings in New York limits the opportunities for squatting. Some buildings were too ruined to invite any attempt, and most of the better buildings presented more hardships to be overcome than the general case in Amsterdam. Dangerous conditions also feature prominently among the stated reasons for evicting squats. Since 1989, several squats have been evicted on the Lower East Side. Five of these squats (i.e. more than half of the total number of evicted squats) were evicted because of the condition of the building. In all cases, squatters asked experts for a second opinion. The experts deemed the buildings repairable. When squatters contested the legitimacy of vacate orders for three buildings in court, they found the judge on their side. A higher judge however overturned this decision.

Technical obstacles to squatting were greater in New York because of the specific dynamics of urban decay. In poor neighborhoods, tenements started deteriorating when the owners found that they could not profitably let the apartments while keeping up the building's maintenance. Operating costs went up and redlining by banks made investment in the buildings impossible. "Milkers", who extract rent while neglecting maintenance, bought up buildings. Living conditions deteriorated and tenants fled the building. Saleable materials could be stripped from the building and arsonists hired in attempts to collect insurance money. Many owners stopped paying city taxes and completely abandoned their property. Because of tax arrears, the city finally took over these buildings.

Alternatively, speculators picked up some of the nearly worthless buildings hoping that the value of the land would rise. In the case of the Lower East Side, the proximity to the financial district fueled this expectation. When this misfired as a result of the real estate slump in the 1970s and 1980s, often abandonment was the result.

More and more abandoned buildings were demolished, which did not help the stability of the neighboring buildings.

In Amsterdam, as Smith (1996: 168) notes, there was never any disinvestment comparable to that in US cities. Abandonment was virtually unheard of and was prevented by state regulation. In decaying working class neighborhoods, the state stepped in with controlled urban renewal programs long before conditions like those in American poor neighborhoods could develop. In Amsterdam, many houses were squatted shortly after the last tenants had been re-housed in the course of urban renewal. Gen- 
erally, the city had some damage done to these houses to prevent squatting; such damage was easily repaired. In Amsterdam, the privately owned buildings, which unlike in New York, were often squatted, tended to be in good condition.

When I asked in New York what kinds of jobs squatters held, construction work came out as the first answer. This works both ways, people with construction skills are not as easily deterred by construction problems that may keep others from squatting, and squatters tended to pick up construction skills by working on their buildings. In the Amsterdam squatter scene, extensive construction work was mainly an optional activity: one could choose to squat a commercial space and convert it into housing.

\section{Squatting and gentrification}

Gentrification is an issue that links the urban regime to the opportunities for squatters to contribute to the push for a lively, low-income people-friendly city. If squatting triggers gentrification this not only undermines this aspect of effectiveness, it also destroys opportunities for further squatting. In Amsterdam, squatting declined during the 1990s. A diminishing supply of empty buildings was one of the factors causing this. The supply was eaten up by the ongoing conversion of buildings into luxury housing (gentrification). Also the renewal process of the 19th century ring of working class neighborhoods had nearly completed its course. On Manhattan, the same happened.

It may seem a reasonable hypothesis that, under a market oriented urban regime, improvements made by citizens to run down neighborhoods (for example by fixing up an abandoned building and chasing drug dealers from the street, or by creating a community garden in an empty lot) can attract property developers.

In the US, there is a long-standing concern that squatting contributes to or causes gentrification. One of the squatters whom I interviewed remarked that: "squatters are the real storm troopers of gentrification". The New York Times quoted a squatter who had lost his home on the Lower East Side when his building was evicted as saying: "I have some contradictions, I see that my person, my culture, my lifestyle facilitates gentrification. It's like I'm a tool of the system. I don't know what to do. I just live my life the way I live it." (Leland, 2000).

Squatters' movements and gentrification do share some characteristics. Both involve an influx of new inhabitants into the neighborhood. In some neighborhoods, for example the east docklands in Amsterdam, squatters were the pioneers. They moved into the empty areas left by stevedoring companies years before "official" warehouse conversion and construction of (partly market-rate) housing started (Buchel and Hogervorst, 1997). Not unlike yuppies, a sizeable proportion of participants in a squatters' movement is relatively well trained, has organizing skills and may look forward to a bright future (Mier and Jansen, 1981). As I indicated earlier, many squatters are rich in cultural and social capital, although not in economic capital. However, squatting is not gentrification for the simple reason that it does not create luxury housing for the affluent. When squatters are precursors of gentrification, this does not have to imply that they actually stimulate it. Nevertheless, Mele's (2000) study of the selling of the Lower East Side suggests that this may be the case.

Gentrification presupposes that the neighborhood concerned can be sold to prospective residents. Since its beginning in the 19th century, the dominant (white) image of the Lower East Side has been characterized by destitution, crime, drugs, danger, substandard housing, minority cultures and radicalism. The 1980s saw a trend of "art based development". Developers tried to make use of the vibrant art scene that had sprung up as a result of the low rents in the neighborhood. Smith et al. (1994: 156) 
stated that "in the gentrification of the East Village, art galleries, dance clubs, and studios have been the shock troops of neighborhood reinvestment, although the extraordinary complicity of the art scene with the social destruction wrought by gentrification is rarely conceded." The effect was that "art tamed the neighborhood" (Smith, 1996: 19). Positive media coverage of the art scene developed into hype. At the same time the municipality tried to curtail unwanted behavior. At the end of the 1980s there were protests and riots following city interventions such as the imposition of a curfew in Tompkins Square Park, the expulsion of homeless from the park and later from an encampment in an empty lot, and the eviction of squatters. These eruptions thwarted the developing image of the Lower East Side as a place that would fit middle class tastes. The 1990s, according to Mele (2000), saw a shift in the dominant image of the Lower East Side. A process of niche marketing developed, in which all the characteristics of the neighborhood, including poverty, drugs, danger and subversive subculture were taken up in a symbolic and sanitized form. A strong example is the Broadway musical "Rent". The emphasis was no longer on selling the neighborhood to affluent employees of the nearby financial district, but on exploiting its exciting image to attract "content developers" to the area. Squatters fit into the postmodern ideal of an interesting cityscape. Harvey (2000: 201) portrayed the Lower East Side, including squatters, as an example of this. However, it seems unlikely that changes in discourse alone bring new affluent inhabitants to a neighborhood. A former squatter from New York pointed out that Giuliani's policy of putting policemen on nearly every corner of the Lower East Side was a more likely stimulant of gentrification.

If squatters did in any way stimulate gentrification, this was contrary to their intentions. Both in New York City and in Amsterdam, squatters often sided with original inhabitants against developers of expensive apartments, for example in the Indische Buurt (early 20th century working class neighborhood on the east side of Amsterdam) (Mier and Jansen, 1981). On Manhattan's Lower East Side, squatters repeatedly attacked the Christadora, a luxury condominium on Thompson Square Park. ${ }^{13}$ Assessments of the effectiveness of this resistance vary. Smith et al. (1994) suggest that squatting is one of the factors that slowed and partly stopped gentrification on the Lower East Side: "a highly visible squatters' movement emerged. The resulting contest for public space, involving demonstrations, police riots, and evictions, suggests that as with the western frontier of the nineteenth century, the 'new' urban frontier is politically as well as economically defined." (Smith, Duncan et al., 1994: 163) (They also pointed to other factors that helped cause gentrification of the Lower East to stall: the housing crisis of the late 1980s, and the exodus of artists.)

Mele (1994) sees the failure of developers to complete the gentrification as an effect of rent control (landlords tried to get rid of tenants by harassing them, or by offering money when harassment had become unfeasible because some of the apartments had already been converted to high rent apartments), "renewable lease laws protecting tenants" and by the presence of low-income housing projects. Sites (1994: 204) concluded: "In retrospect, Lower East Side resistance did not halt gentrification nor did it create strong safeguards against displacement." One of the New York squatters I consulted answered the question: "can one stop gentrification" by saying: "you can only slow it down".

13 Squatters threw stones through the glass lobby doors and second-floor windows, and dumped garbage in the lobby. 


\section{Competition between squatters and providers of low-income housing rehabilitation}

I will now conclude the comparison by focusing on the one area in which a marketoriented regime seems to offer more opportunities for squatting: the arena of lowincome housing rehabilitation.

In New York's squatting history, there is dramatically more competition and conflict between squatters on the one hand, and groups that work with the state to create what they see as affordable housing on the other hand than in Amsterdam.

Abu-Lughod (1994: 252-253) noted that "housing reformers" and squatters were increasingly locked into a zero-sum struggle over the very same properties." She stated that this caused a decline in public interest and support for the squatters.

In the history of organized squatting on the Lower East Side, squatters of nine buildings or clusters of buildings took action to avert threats of eviction. Some of the tactics in the repertoire were:

Legal action

Street protest or lock down action targeting a (non-profit) property developer

Disruption of meetings

Nonviolent resistance (e.g. placing oneself in the way of a demolition ball, lining up in front of the building)

- $\quad$ Fortification of the building(s)

Building barricades in the street

Throwing substances at policemen approaching the building

Re-squatting the building after eviction

Six of the conflicts involved competing low income housing claims (see Table 1). In three cases, such claims were absent (see Table 2). ${ }^{14}$

Table 1 Lower East Side conflicts involving low income housing claims

\begin{tabular}{|c|c|c|}
\hline location & Name & outcome \\
\hline E $5^{\text {th }}$ St. 537-39 & & evicted in 1997 \\
\hline Av C 21-23 & Umbrella House & legalized in 2002 \\
\hline $\begin{array}{l}\mathrm{E} 4^{\text {th }} \text { St. between } \\
\text { Avenues B and C }\end{array}$ & ABC Community Center & evicted in 1989 \\
\hline 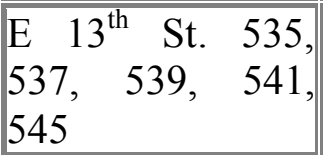 & & evicted in $1995 / 1996$ \\
\hline Av D/ $10^{\text {th }}$ St. & Glass House & evicted in 1994 \\
\hline Rivington St. 156 & ABC No Rio & survived (2002) as an arts center \\
\hline
\end{tabular}

Table 2 Lower East Side conflicts not involving low income housing claims

\begin{tabular}{|c|c|c|}
\hline location & Name & $\begin{array}{c}\text { outcome } \\
\end{array}$ \\
\hline E $9^{\text {th }}$ St. 713 & Dos Blockos & evicted in 1999 \\
\hline E $7^{\text {th }}$ St. 272 , & & 274 and 278 legalized in 2002 \\
\hline
\end{tabular}

${ }^{14}$ Tables 1 and 2 were obtained by combining data from internet resources provided by the movement, newspaper articles retrieved from the Lexis-Nexis database, interviews and documents found in the files of Community Board \#3. 


\begin{tabular}{|c|c|c|}
\hline location & Name & outcome \\
\hline 274,278 & & \\
\hline E $8^{\text {th }}$ St. 319 & & evicted in 1989 \\
\hline
\end{tabular}

In the 1990s, most conflicts on the Lower East Side involved buildings that had been claimed by housing organizations for development as low- or moderate income housing.

In Amsterdam there were a few cases in which squatters resisted being displaced for community supported construction of low-income housing. (A block of 19th century tenements on the Blasiusstraat, a similar complex in the Kinkerstraat, warehouses in the Conradstraat, a warehouse on the Houtmankade. Resistance in the Blasiusstraat and the Conradstraat led to clashes with the police. In the case of the warehouse on the Houtmankade, a compromise was reached which allowed the squatters to retain the top floor.) In view of the scale of squatting in Amsterdam these cases are merely incidents. Thus, in Amsterdam, conflicts between squatters and housing groups over buildings were rare.

At first sight, an obvious interpretation of this difference is that it is yet another indication that the opportunities for squatting in New York were fewer than in Amsterdam. In New York, squatters sooner or later tended to face accusations that they were blocking the development of low-income housing. It was as though there was a mysterious mechanism by which after every squatting action, a non-profit initiative popped up that claimed the building. For the squatters, this caused legitimation problems. It cannot be excluded that there may have been non-profit developers or municipal officials who systematically targeted squatted buildings for development as lowor moderate-income housing. However, a different picture emerges when we look more closely into the relation between squatting and low-income housing development in Amsterdam. In Amsterdam, in 1981, slightly more than half of all squatters lived in the decaying working class neighborhoods that were built at the end of the 19th century and the beginning of the 20th century (Van der Raad, 1981: 37). Virtually all squats in these areas were eventually replaced by low-income housing. With very few exceptions, squatters in these areas left voluntarily without protest in time for the scheduled demolition and construction work to start. They tended to view their occupancy of run down buildings as temporary.

In analyses of squatting in the Netherlands this is something that has tended to be overlooked.15 It is one of those facts that reveal their significance when a comparison is made with another city in which it is different. Could the explanation be that among squatters in Amsterdam, there was deep respect for law and order? This is very unlikely, since in 1980, squatting-related incidents produced some of the largest riots in post-war Dutch history. A more plausible explanation should take into account that the investments made in time and money by squatters in Amsterdam's working class neighborhoods tended to be smaller than those made by their New York counterparts: the technical condition of squattable buildings in New York was worse. A further salient point is that in Amsterdam, the claims laid by the municipality and the developers of low-income housing were so robust, that squatters did not contest these. In Amsterdam, there was a relatively strong consensus about how new low-income housing was to be created. Most squatters either shared this consensus, or at least felt that it would be useless to move against it.

\footnotetext{
${ }^{15}$ One exception: (Adriaenssen, 1996: 138)
} 
This consensus was based on five features of the development of low-income housing in old working-class urban areas that set Amsterdam apart from New York.

\section{Affordability}

In Amsterdam, rents in new low-income housing were higher than in the housing that it replaced. Nevertheless, since 1978 national and municipal policy has been guided by the idea of "building for the neighborhood". This means that in terms of affordability and number and size of apartments, the inhabitants of a neighborhood should have the opportunity to stay after renewal. State regulation made sure that design for construction and rehabilitation proceeded within strict budget limits while adhering to prescribed quality standards. Renewal was subsidized to keep rents down. Individual rent subsidies, based on income, were made available to every tenant who qualified for it. This further increased affordability. The tenants affected had the right to be rehoused in their own neighborhood (Heijdra, 1989: 75). This policy replaced an earlier type of policy that aimed at the elimination of the old working class neighborhoods. These were to give way to lower density housing that would attract wealthier people with families, and office space and roads. Resistance and prohibitive cost of displacement had put an end to this form of renewal. After 1978, tenants' organizations kept politicians under pressure to control rents after renewal. The result was that housing in large Dutch cities continued to be dominated by rented, affordable apartments (SCP, 1998).

In New York, rents in newly constructed or renovated housing that carried the label of "low-income rent" were often out of reach for the displaced tenants. In the 1990s, housing subsidies, apart from tax abatements, had virtually disappeared. Moreover, agreements with developers allowed them to charge market rate rents after fifteen years.

2 Demarcation between profit-oriented vs. non-profit development

In Amsterdam, there was a clear demarcation between the construction of low-income housing and the construction of free-market apartments for profit. The low-income units were built for housing associations that restricted themselves to managing lowincome housing. Not only were these associations non-profit but few people doubted that their management operated in the interests of low-income tenants. The strict demarcation in Amsterdam between for profit and non-profit development increased the legitimacy of low-income housing rehabilitation and development.

In New York's housing sector, the demarcation between profit and non-profit was not as clear. The latter was characterized by partnerships with profit-oriented organizations. Non-profit organizations, which included neighborhood groups transformed by cooptation, were often accused of channeling wealth to their executives in the form of high salaries. Squatters chose to denote these as "poverty pimps".

\section{Reliability and transparency}

In Amsterdam, plans for construction or rehabilitation of low-income tended to be realized, although often more slowly than expected. In New York, there was not much certainty that plans for low-income housing would be carried out (Sante, 1995).16 In New York, it was often difficult to find out what the plans for a particular building

\footnotetext{
${ }^{16}$ Examples of squats evicted in New York after which plans for low-income housing did not materialize East 13th street, Av C/10th str, Glass House (the proposed site for a home for AIDS patients that did not become a reality.
} 
were, and also to assess how realistic these plans were. New York's track record of low-income rehabilitation was unconvincing.

\section{Level of democratic planning}

In Amsterdam, getting input from prospective tenants, who wanted to make the transition from old to new housing, was often part of the planning process. Few squatters would dare to hinder plans that were developed in this way.

\section{Recognition of squatters' needs}

Gradually, municipal officials in Amsterdam came to recognize squatters' housing needs. Squatters who had been in their buildings for several years became entitled to re-housing.

These five differences explain why, in Amsterdam, squatters (with minor exceptions) kept out of the way of low-income construction and rehabilitation, while in New York squatters did not vacate their buildings on the announcement of plans for low-income construction and rehabilitation. In one case, $\mathrm{ABC}$ No Rio, squatters won a conflict by putting pressure on a non-profit developer, Asian Americans for Equality, accusing it of "greed", "profiteering" and "corruption." Protest on this organization's doorstep led to media coverage in which its critics could voice their concerns. The low-income housing industry of New York, because it operated in a gray zone between public and private interest, was vulnerable to this kind of criticism. Thus, when reasoning in a functionalist way: the privatization of poverty gave urban movements a potential role as watchdogs of the poverty industry that operated in the third sector between state and market. On the other hand, officials with a stake in the New York poverty industry constantly attacked squatters for not being the real poor or the real homeless.

The flip side was that social conflict in New York tended to remain contained within the low-income housing arena. Squatters fought non-profit developers and community board members) who also professed to support low-income housing. (The community board is an advisory committee representing the neighborhood; squatters frequently disrupted its meetings). The opaque arena of low-income housing development, riddled with complex deals involving cross-subsidies (market-rate development subsidizing low-rent development) and brokered tax abatements, populated by actors with varying agendas and varying levels of naiveté, guaranteed confusion. There was a huge gap between expectations in terms of affordable housing and results (Abu-Lughod, 1994). There were also some unintended consequences. For example, a cross-subsidy plan negotiated by housing activists in the 1980s caused the destruction of community gardens around the year 2000 .

In the meantime, political decision-makers who could press for state investment in low-income housing were effectively shielded from squatters' protests. In Amsterdam, riots caused them considerable stress (Anderiesen, 1981). Also, in Amsterdam, squatters gave for-profit developers, and the banks that financed them, difficult times (Adilkno, 1994).

\section{Conclusion}

The argument of this paper is summarized in Table 3. The main conclusions follow below. Our two city comparison has shown how, perhaps paradoxically, a marketoriented regime with little redistributive and regulative commitment to low-income 
housing offers less opportunities for squatting than a regime that is much more based on redistribution and planning.

The comparison confirmed the proposition that a market-oriented regime encourages the cooptation of movement groups as service providers, which in turn implies the abandonment of squatting.

A squatters' movement such as the one in Amsterdam is immune to cooptation because it involves squatting not only as a means but also as an end. It proved to be possible to start such a movement in New York, counter to the structural trend in the US. This is an example of diverse causal chains leading to similar outcomes (Pickvance, 2001: 20-24).

However, the opportunity structure facing potential squatters in New York was less favorable in terms of:

- Protection of property against squatters (causing squatters in New York to stick to city property, while squatters in Amsterdam could also target real estate developers and speculators).

- Access to municipal officials (squatters in Amsterdam had easy access to municipal officials; this was part of a pattern of flexible institutionalization).

- The technical condition of available buildings.

However there is one respect in which squatters under a market-oriented regime have more leeway: the renovation of low-income housing, because this is such a disorganized process. The implications are twofold: radicals can act as watchdogs when coopted groups risk falling prey to the "Weber-Michels" scenario (from social movement to managerial self-interest focused organization) and expose the effects of the privatization of poverty. But, on the other hand, conflict tends to be concentrated in a very local arena, leaving big real estate and banking, and big politics comfortably unaffected.

Obstacles to the development of an effective squatters' movement in the US are formidable. Legal and technical problems get in the way. Also there is the problem of location. In the US there is an abundance of abandoned properties. Sometimes, for example in Michigan, they are made available for free to citizens who are willing to fix them up. Often, these abandoned properties are not in places that attract the nonwealthy, but rich in cultural and social capital type of people who make up the core of a squatters' movement. (During the crack epidemic, the Lower East Side was unsafe; this was offset by the cultural attractiveness of the area.) And when people start squatting (or community gardening), they may find that they attract gentrification and competition from the poverty industry. Moreover, the New York squatters' movement revealed organizational difficulties. When interviewed, a Dutch-American squatter exclaimed: "we could have squatted so many more buildings on the Lower East Side, but we did not get it organized". One of the things that was lacking, was an advisory service for prospective squatters. New York squatters tended to feel that squatting in the Netherlands was "more professional". But the structures of the Amsterdam squatters' movement took thirteen years to develop (from 1965 until 1978), although its resources were plentiful. Many young people had a lot of time to invest. They belonged to a "lost generation" for whom there were few jobs available. Also many students were not in a hurry to complete their studies, also because of the lack of jobs. Being funded by welfare payments or student grants, they were eager to engage in productive work outside the labor market.

However, it remains an open question whether a creative storm such as the one that swept Amsterdam could revitalize urban wastelands in the US. Equally open is the question whether in the US, urban movements could escape from the confines of the 
low-income housing arena and become a political force aimed at serious redistributive investment in housing.

Post-Fordist theory tends to recognize only one viable scenario for urban movements: by being co-opted, making the best of the opportunities provided by the retreating state. However, third sector disorganization and the blurring of the distinction between public and private interest opens up new opportunities for movements that preserve an oppositional identity. 
Table 3 Summary of the argument

\begin{tabular}{|c|c|c|}
\hline & New York City & Amsterdam \\
\hline Urban regime & market oriented & regulation \\
\hline Affordable housing & shortage & shortage \\
\hline $\begin{array}{l}\text { Availability of empty } \\
\text { buildings }\end{array}$ & abundant until mid 1990s & abundant until mid 1990s \\
\hline \multicolumn{3}{|c|}{ Squatting employed as a tactic by a housing movement } \\
\hline Occurrence & 1970-1972 (mainly) & - \\
\hline Susceptible to cooptation & $\begin{array}{l}\text { yes, resulting (combined with } \\
\text { repression) in the disappear- } \\
\text { ance of visible squatting after } \\
1972 \text {. }\end{array}$ & - \\
\hline \multicolumn{3}{|l|}{ Squatters' movement proper } \\
\hline Occurrence & $1983-2002>$ & $1965-2002>$ \\
\hline Susceptible to cooptation & $\begin{array}{l}\text { no (terminal institutionaliza- } \\
\text { tion instead) }\end{array}$ & $\begin{array}{l}\text { no (flexible institutionaliza- } \\
\text { tion instead) }\end{array}$ \\
\hline Longevity of squats & may exceed 16 years & may exceed 16 years \\
\hline $\begin{array}{l}\text { Protection of owners' } \\
\text { right to leave property un- } \\
\text { used }\end{array}$ & strict & qualified \\
\hline $\begin{array}{l}\text { Squatters' access to the } \\
\text { political system }\end{array}$ & direct access impossible & easy \\
\hline $\begin{array}{l}\text { Original technical state of } \\
\text { squatted buildings }\end{array}$ & poor & $\begin{array}{l}\text { ranging from poor to out- } \\
\text { standing }\end{array}$ \\
\hline $\begin{array}{l}\text { Ownership of squatted } \\
\text { buildings }\end{array}$ & public & both public and private \\
\hline $\begin{array}{l}\text { Conflict between squatters } \\
\text { and the purely for profit } \\
\text { real estate sector }\end{array}$ & little & frequent, wide-ranging \\
\hline $\begin{array}{l}\text { Conflict between squatters } \\
\text { and (legal) non-profit de- } \\
\text { velopers of low-income } \\
\text { housing }\end{array}$ & $\begin{array}{l}\text { Frequent, caused by competi- } \\
\text { tion between squatters and } \\
\text { low-income housing develop- } \\
\text { ers that operate in an opaque, } \\
\text { grey zone between public and } \\
\text { private interest }\end{array}$ & $\begin{array}{l}\text { Rare, as a result of a broad } \\
\text { consensus about low-income } \\
\text { housing redevelopment, } \\
\text { based on affordability, a } \\
\text { clear demarcation between } \\
\text { profit oriented vs. non-profit } \\
\text { development, reliability and } \\
\text { transparency, democratic } \\
\text { planning and recognition of } \\
\text { squatters' needs }\end{array}$ \\
\hline Scope of conflict & $\begin{array}{l}\text { contained on neighborhood } \\
\text { level, and within arena of low } \\
\text { income housing development }\end{array}$ & $\begin{array}{l}\text { impinged on municipal and } \\
\text { national politics, real estate } \\
\text { interests and banking }\end{array}$ \\
\hline
\end{tabular}




\section{References}

Abu-Lughod, J. L. (1994). The battle for Tompkins Square Park. From urban village to East Village. The battle for New York's Lower East Side. J. L. Abu-Lughod. Oxford UK \& Cambridge USA, Blackwell: 233-266.

Abu-Lughod, J. L. (1994). Defending the Cross-Subsidy Plan: The Tortoise Wins Again. From urban village to East Village. The battle for New York's Lower East Side. J. L. Abu-Lughod. Oxford UK \& Cambridge USA, Blackwell: 313-332.

Adriaenssen, L. (1996). Een dwarse buurt. Het herscheppingsverhaal van de Staatsliedenbuurt en Frederik Hendrikbuurt 1971-1996. Amsterdam, Wijkcentrum Staatslieden- Hugo de Grootbuurt.

Adilkno (1994). Cracking the Movement. Squatting Beyond the Media. New York, Autonomedia.

Amann, R. (1985). Der moralische Aufschrei. Presse und abweichendes Verhalten am Beispiel der Hausbesetzungen in Berlin. Frankfurt/Main, Campus Verlag.

Anderiesen, G. (1981). "Tanks in the streets: the growing conflict over housing in Amsterdam." International journal of urban and regional research 5(1): 83-95.

Anon (1972). "Logement et lutte de classes: compte-rendu d'une pratique militante de quartier á Paris." Espaces et societes 6-7: 59-88.

Artkämper, H. (1995). Hausbesetzer, Hausbesitzer, Hausfriedensbruch. Berlin, Springer-Verlag.

Bailey, R. (1973). The Squatters. Harmondsworth, Penguin.

Berger, P. L. and T. Luckmann (1967). The social construction of reality. A treatise in the sociology of knowledge. London, Allen Lane The Penguin Press.

Borgos, S. (1984). "The ACORN squatters' campaign." Social policy 15(1): 17-26.

Borgos, S. (1986). "Low-income Homeownership and the ACORN Squatters Campaign" in: R. G. Bratt, C. Hartman and A. Meyerson (eds). Critical perspectives on housing. Philadelphia, N.J., Temple University Press: 428-446.

Breek, P. and F. d. Graad (2001). Laat duizend vrijplaatsen bloeien. Onderzoek naar vrijplaatsen in Amsterdam. Amsterdam, De Vrije Ruimte.

Brotherton, M. A. (1978). Conflict of interest, law enforcement, and social change: a case study of squatters on Morningside Heights. Ann Arbor, University Microfilms International.

Buchel, P. and B. Hogervorst (1997). The Turning Tide. The user's role in the redevelopment of harbour buildings in North-West Europe. Amsterdam, The Ij Industrial Buildings Guild / De Appelbloesempers.

Cant, D. (1979). "Squatting and private property rights." International journal of urban and regional research 3(3): 404-417.

Castells, M. (1977). The Urban Question. Londen, Arnold.

Castells, M. (1983). The city and the grassroots : a cross-cultural theory of urban social movements. London, Edward Arnold.

Cherki, E. (1973). "Le mouvement d'occupation de maisons vide en France." Espaces et societes 9: 69-91.

Corr, A. (1999). No trespassing. Squatting, rent strikes and land struggles worldwide. Cambridge MA, South End Press.

della Porta, D. and D. Rucht (1995). "Left-Libertarian Movements in Context: A Comparison of Italy and West Germany, 1965-1990." in: J. C. Jenkins and B. Klandermans (eds.) The Polictis of Social Protest. Comparative Perspectives on States and Social Movements, London, UCL Press: 229-272.

Draaisma, J. and P. v. Hoogstraten (1983). "The squatter movement in Amsterdam." International journal of urban and regional research 7(3): 405-416. 
Dryzek, J. S. (1996). "Political Inclusion and the Dynamics of Democratization." The American Political Science Review 90(3): 475-487.

Duivenvoorden, E. (2000). Een voet tussen de deur. Geschiedenis van de kraakbeweging 1964-1999. Amsterdam, Arbeiderspers.

Duriez, B. and M. Chauvière, Eds. (1992). La bataille de squatteurs et l'invention du droit au logement, 1945-1955. Les Cahiers du G.R.M.F. Villeneuve d'Ascq, Groupement pour la Recherche sur les Mouvements Familiaux.

Erlanger, S. (1987). New York turns squatters into homeowners. New York Times., October 12, Section A, page 1.

Esping-Andersen, G. (1990). The three worlds of welfare capitalism. Cambrdge, Polity Press.

Fainstein, S. (2000). "The egalitarian city. Images of Amsterdam. " in: . L. Deben, W. Heinemeier and D. v. d. Vaart (eds) Understanding Amsterdam Essays on economic vitality, city life and urban form Amsterdam, Het Spinhuis: 93-115.

Friend, A. (1980). The post war squatters. Squatting. The real story. N. Wates and C. Wolmar. London, Bay Leaf Books: 110-119.

Goodwin, J. and J. M. Jasper (1999) "Caught in a winding, snarling vine: the structural bias of political process theory" Sociological Forum 14 (1): 27-54

Harvey, D. (2000). Social Justice, Postmodernism, and the City. The City Reader. Second edition. R. T. LeGates and F. Stout. London / New York, Routledge: 199-207. Heijdra, T. (1989). De Pijp. Monument van een wijk. Amsterdam, De Miliano.

Hollister, R. (1972). "The politics of housing: squatters." Society(9 (July/Aug)): 4662.

Huijsman, C., H. Pruijt and I. Strubbe (1998). "Projectgroep Woonbeleid en Kraakpolitiek. Een stroom van werkgroepen, onderzoeken en papers" in: H. Kalt, J. Kok, M. v. d. Tweel and H. v. Zijl. (eds.). Gepakte Stad Special. Saar, de Schat van Amsterdam, Amsterdam, KROA: 38-39

Johnstone, C. (2000). Housing and class struggles in post-war Glasgow. Class struggle and social welfare. M. Lavalette and G. Mooney. London, Routledge: 139-154.

Kallenberg, F. (2001). Desire is speaking. Utopian rhizomes. Contemporary Utopian Struggles. Communities between modernism and postmodernism. S. Poldervaart, H. Jansen and B. Kesler. Amsterdam, Aksant: 91-99.

Katz, S. and M. Mayer (1985). "Gimme shelter: self-help housing struggles within and against the state in New York City and West Berlin." International journal of urban and regional research 9(1): 15-47.

Kinghan, M. (1977). Squatters in London. London, Institute of community studies / Shelter. National campaign for the homeless.

Kriesi, H., R. Koopmans, J. W. Duyvendak and M Guigni (1995). New Social Movements in Western Europe. A Comparative Analysis. London, UCL Press.

Lawson, R. (1986). "Tenant Responses to the Urban Housing Crisis, 1970-1984." in R. Lawson (ed) The Tenant Movement in New York City, 1904-1984.. New Brunswick, New Jersey, Rutgers University Press: Chapter 5, www.tenant.net.

Leland, J., (2000), On Avenue C, Renewal and Regret, The New York Times, August 3, Section F; Page 1

Leland, J., (2000), On Avenue C, Renewal and Regret, The New York Times, August 3, Section F; Page 1

Lowe, S. (1986). Urban Social Movements. The City After Castells. New York, St. Martin's Press.

Mamadouh, V. (1992). De stad in eigen hand. Provo's, kabouters en krakers als stedelijke sociale beweging. Amsterdam, SUA. 
Mayer, M. (1993). The career of urban social movements in West Germany. Mobilizing the community: local politics in the era of the global city. R. Fisher and J. Kling. Newbury Park, Sage. 41: 149-170.

Mayer, M. (1998). The Changing Scope of Action in Urban Politics: New Opportunities for Local Initiatives and Movements, in: Wolff, R.; Schneider, A.; Schmid, C.; Klaus, P.; Hofer, A. and H. Hitz (INURA Zürich) (eds) Possible Urban Worlds: urban strategies at the end of the 20th century, Basel, Birkhaüser, 66-75, http://userpage.fuberlin.de/ mayer/mm/changing.htm

Mayer, M. (2000). Post-Fordist City Politics The City Reader. Second edition. R. T. LeGates and F. Stout. London / New York, Routledge: 229-239.

Mele, C. (1994). The process of gentrification im Alphabet City. From urban village to East Village. The battle for New York's Lower East Side. J. L. Abu-Lughod. Oxford UK \& Cambridge USA, Blackwell: 178-188.

Mele, C. (2000). Selling the Lower East Side. Culture, real estate and resistance in New York City. Minneapolis, University of Minnesota Press.

Mier, N. and P. Jansen (1981). Daar komen de krakers, paper Sociology of the built environment, University of Amsterdam:. Amsterdam

Mulhak, R. (1983). Der Instandbetsetzungskonflikt in Berlin. Grossstadt und neue soziale Bewegungen. P. Grottian and W. Nelles. Basel, Birkhaüser Verlag. 1: 205-252.

Pickvance, C. G. (2001). "Four varieties of comparative analysis." Journal of Housing and the Built Environment 16(1): 7-28.

Piven, F. F. and R. A. Cloward (1977). Poor people's movements. Why they succeed, how they fail. New York, Pantheon Books.

Platt, S. (1980). A decade of squatting. The story of squatting in Britain since 1968. Squatting. The real story. N. Wates and C. Wolmar. London, Bay Leaf Books: 14103.

Platt, S. (1985). Who Are the Squatters Now? New Society. 73: 331-334.

Priemus, H. (1983). "Squatters in Amsterdam: urban social movement, urban managers or something else?" International journal of urban and regional research 7(3): 417427.

Pruijt, H. (1984). De Cityvorming Gekraakt? Unpublished MA thesis, Department of Sociology, Universiteit van Amsterdam.

Pruijt, H. (1985). "Cityvorming gekraakt? Invloed van actiegroepen op de stedelijke planning in Amsterdam." Agora 1(4): 4-5 \& 10

Sante, L. (1995). New York's attack on itself. New York Times.. 4 june 1995, New York: section 14 page 15.

Schuckink Kool, M. (2001). De rechtspositie van krakers jegens de overheid. De bevoegdheden van de overheid tegen krakers in theorie en in de praktijk. Den Haag, Master of Law thesis, Open Universiteit.

Schwartz, J. (1986). Tenant Power in the Liberal City, 1943-1971. The Tenant Movement in New York City, 1904-1984. R. Lawson. New Brunswick, New Jersey, www.tenant.net, Rutgers University Press: Chapter 4.

SCP (1998). Sociaal en Cultureel Rapport 1998. The Hague, Sociaal Cultureel Planbureau / SDU.

Selznick, P. (1949). TVA and the grass roots : a study in the sociology of formal organization. Berkeley, University of California Press.

Sites, W. (1994). Public action: New York City Policy and the gentrification of the Lower East Side. From urban village to East Village. The battle for New York's Lower East Side. J. L. Abu-Lughod. Oxford UK \& Cambridge USA, Blackwell: 189-211. 
Smith, N., B. Duncan and L. Reid (1994). From disinvestment to reinvestment: mapping the urban 'frontier' in the Lower East Side. From urban village to East Village. The battle for New York's Lower East Side. J. L. Abu-Lughod. Oxford UK \& Cambridge USA, Blackwell: 149-165.

Smith, N. (1996). The new urban frontier. Gentrification and the revanchist city. London and New York, Routledge.

Soja, E. (2000). The stimulus of a little confusion. A contemporary comparison of Amsterdam and Los Angeles. Understanding Amsterdam. Essays on economic vitality, city life and uban form. L. Deben, W. Heinemeijer and D. v. d. Vaart. Amsterdam, Het Spinhuis: 117-141.

Tarrow, S. (1994). Power in movement. Social movements, collective action and politics. Cambridge, Cambridge University Press.

Tobocman, S. (1999). War in the neighborhood. New York, Autonomedia.

Tromp, B. (1981). "Kraken als actievoeren: een verkenning." Sociologische gids 28(1): 23-35.

Van der Loo, E. Snel and B. van Steenbergen (1984). Een wenkend perspectief Nieuwe sociale bewegingen en culturele veranderingen. Amersfoort, De Horstink.

Van der Pennen, T., A. Bertram, L. de Boer and I. van Vliet. (1983). Kraken en volkshuisvesting. Leiden, R.O.V.

Van Kleunen, A. (1994). The squatters: a chorus of voices ... but is anyone listening? The battle for Tompkins Square Park. From urban village to East Village. The battle for New York's Lower East Side. J. L. Abu-Lughod. Oxford UK \& Cambridge USA, Blackwell: 285-312.

Van der Raad, J. W. (1981). Kraken in Amsterdam. Amsterdam, Roelof Kellerstichting.

Van Noort, W. (1988). Bevlogen bewegingen. Een vergelijking van de antikernenergie, kraak- en milieubeweging. Amsterdam, SUA.

Von Hassell, M. (1996). Homesteading in New York City, 1978-1993. The divided heart of Loisaida. Westport, Bergin \& Garvey.

Waldman, A, (2001), A Rebuilder In the Bronx Scales Back, The New York Times, March 29, Section B; Page 1

Warren, R. L., S. M. Rose and A. F. Bergunder (1974). The structure of urban reform : community decision organizations in stability and change. Lexington, Mass, Lexington Books.

Watkinson, D. (1980). The erosion of squatters rights. Squatting. The real story. N. Wates and C. Wolmar. London, Bay Leaf Books: 158- 163.

Zahn, E. (1993). Das unbekannte Holland. Regenten, Rebellen und Reformatoren. München, Goldmann. 